\title{
PENGARUH PENDIDIKAN TEMAN SEBAYA (PEER EDUCATION) KESEHATAN MENSTRUASI TERHADAP KESIAPAN SISWI SD MENGHADAPI MENSTRUASI AWAL
}

\author{
Istinengtiyas Tirta Suminar ${ }^{1}$, Diah Nur Anisa ${ }^{2}$ \\ ${ }^{1,2}$ Universitas 'Aisyiyah \\ e-mail: istinengtiyas.ts@unisayogya.ac.id
}

\begin{abstract}
ABSTRAK
Remaja yang akan mengalami menstruasi pertama membutuhkan kesiapan mental yang baik dan harus diberikan pengetahuan tentang proses menstruasi dan juga informasi tentang menarche agar siap secara mental untuk menghadapinya. Salah satu media anak dalam memperoleh informasi adalah dari teman sebayanya. Pendidikan melaui teman sebaya (peer education) merupakan salah satu metode yang paling sering digunakan untuk pelaksanaan intervensi promosi kesehatan pada remaja. Penelitian ini bertujuan untuk melihat pengaruh pendidikan teman sebaya (peer education) kesehatan menstruasi terhadap kesiapan menghadapi menarche siswi SD 2 Jambidan Banguntapan Bantul Yogyakarta. Metode penelitian adalah pre experimental dengan desain one group pretest - posttest. Penelitian ini dilakukan pada bulan Agustus 2019 di SD 2 Jambidan, Banguntapan, Bantul, Yogyakarta dengan jumlah responden 39 orang. Uji statistik Paired $t$ test digunakan untuk melihat pengaruh pendidikan teman sebaya (peer education) kesehatan menstruasi terhadap kesiapan menghadapi menarche. Kesiapan responden dalam menghadapi menarche sebelum intervensi peer education berada pada kategori baik dan cukup masing-masing sebanyak 16 (41\%) responden. Kesiapan responden dalam menghadapi menarche sesudah intervensi peer education berada pada kategori baik sebanyak $27(69,2 \%)$ responden. Hasil uji paired t test menunjukkan nilai signifikansi $0,03(\mathrm{p}<0.05)$. Berdasarkan hasil penelitian ini, maka dapat disimpulkan bahwa terdapat perbedaan antara kesiapan responden sebelum dan sesudah intervensi peer education. Metode peer education dapat digunakan sekolah dalam upaya meningkatkan kesiapan siswi dalam menghadapi menstruasi awal.
\end{abstract}

Kata kunci: Kesiapan, Menstruasi awal, Peer Education

\begin{abstract}
Adolescents who are about to experience their first menstruation require good mental readiness and must be given knowledge about the menstrual process and also information about menarche to be mentally ready to face it. One of the children's media in obtaining information is from their peers. Peer education is one of the most frequently used methods for implementing health promotion interventions for adolescents. This study aims to determine the influence of peer education on menstruation toward readiness of menarche. This study uses a pre experimental research method with one group pretest posttest design. This study has conducted in August 2019 at SD 2 Jambidan, Banguntapan, Bantul, Yogyakarta with 39 respondents. Paired t test statistical test was used to assess the effect of peer education on menstrual health on readiness to face menarche. The readiness of respondents in facing menarche before the peer education intervention was in the good category and quite as much as each of 16 (41\%) respondents. The readiness of respondents in facing menarche after peer education intervention was in a good category of 27 (69.2\%) respondents. Paired T test results
\end{abstract}


obtained a significance value of 0.003 ( $p<0.05$ ). Based on the results of this study, it can be concluded that there are differences between the readiness of students before and after menstrual health peer education interventions. The peer education method can be used to increase student's readiness in confront early menstruation.

Keywords: Readiness, Menarche, Peer Education

\section{PENDAHULUAN}

Masa pubertas merupakan kematangan tahap perkembangan yang ditandai dengan kematangan organ reproduksi dengan berfungsinya hormon-hormon seksual pada remaja (Janiwarty \& Pieter, 2013). Berdasarkan Survei Penduduk Antar Sensus 2015 menunjukkan penduduk usia 10-24 tahun mencapai $42.061,2$ juta jiwa atau sebesar $16,5 \%$ dari total penduduk Indonesia (Lembaga Demografi FEB UI, 2017). DIY jumlah remaja putri yang berusia 1019 tahun sekitar 32.244 jiwa (Kemenkes RI, 2017).

Salah satu tanda pubertas pada perempuan adalah mulai terjadinya menstruasi awal yang disebut menarche. Dalam kondisi menarche, organ-organ reproduksi wanita mulai berfungsi dan akan terjadi perubahan fisik yang ditandai dengan tumbuhnya payudara, pinggang melebar, dan rambut-rambut halus di daerah ketiak dan kemaluan (Proverawati \& Misaroh, 2009).

Ketika mengalami menstruasi awal, anak akan memberikan reaksi emosional negatif terhadap menstruasi awal (Gurkan, 2015). Dampak negatif akan mungkin muncul pada anak dalam menghadapi menstruasi awal seperti gangguan psikologis, ketakutan, kecemasan, mudah tersinggung, marah, perubahan pola makan dan perubahan pola tidur karena datangnya menstruasi. Anak yang belum siap menghadapi menstruasi awal akan timbul penolakan proses fisiologis dan menganggap bahwa menstruasi merupakan kondisi yang mengancam (Puspita et al., 2015).

Anak yang akan mengalami menstruasi pertama membutuhkan kesiapan mental yang baik dan harus diberikan pengetahuan tentang proses menstruasi dan juga informasi tentang menstruasi awal agar siap secara mental untuk menghadapinya. Kesiapan pada anak perempuan sangat diperlukan, karena pada saat datangnya menstruasi awal akan menimbulkan reaksi positif atau pun negatif bagi anak tersebut.

Faktor-faktor yang mempengaruhi kesiapan menstruasi awal antara lain, tingkat pengetahuan, usia, lingkungan, keadaan fisik, dukungan keluarga dalam hal ini adalah orangtua, dan informasi (Setiowati, 2015). Sumber informasi pada anak bisa didapatkan dari pengaruh teman sebaya. Teman sebaya pada remaja memberikan pengaruh besar karena remaja lebih banyak mengahabiskan waktu dengan teman sebayanya. Oleh karena remaja lebih banyak berada diluar rumah bersama teman sebaya, maka dapat dimenegrti pengaruh teman sebaya lebih besar daripada keluarga (Hurlock, 2009).

Peer group merupakan salah satu agen sosialisasi bagi individu. Dalam kelompok inilah berlangsungnya penurunan nilai budaya suatu kebudayaan, norma, acuan bertingkah laku, sistem dan pola berfikir sekelompok masyarakat, dan sebagainya. Semakin dewasa seseorang maka akan semakin kuat pula pengaruh dari peer group, 
sehingga pengaruh dari keluarga akan semakin melemah.

Teman sebaya mempunyai kontribusi yang dominan dan mampu menjadi contoh (Modeling) dalam berperilaku terkait kesehatan (Morta \& Farhat, 2010). Alasan yang diungkapkan, remaja lebih mempercayai teman sebaya karena cenderung terbuka dalam membicarakan masalah kesehatan yang dihadapinya. Apabila informasi yang diperoleh tidak benar, maka akan muncul persepsi negatif pada anak sehingga akan muncul rasa malu saat mengalami menstruasi awal dan dapat timbul beberapa gangguangangguan berupa; pusing, mual dan haid yang tidak teratur (Jayanti \& Purwanti, 2012).

Hasil studi pendahuluan yang dilakukan peneliti di SD 2 Jambidan Banguntapan Bantul didapatkan bahwa 6 dari 10 remaja yang diwawancarai menyatakan belum siap menjalani menstruasi. Mereka merasa takut akan aktifitas yang terganggu selama menstruasi. Dengan hal tersebut peneliti tertarik melakukan penelitian tentang pengaruh pendidikan teman sebaya (peer education)kesehatan menstruasi terhadap kesiapan menghadapi menstruasi awal. Tujuan penelitian ini adalah untuk melihat pengaruh pendidikan teman sebaya (peer education) kesehatan menstruasi terhadap kesiapan menghadapi menstruasi awal siswi SD 2 Jambidan Banguntapan Bantul Yogyakarta.

\section{METODOLOGI PENELITIAN}

Penelitian menggunakan metode penelitian pre experimental dengan desain one group pretest-posttest. Penelitian dilakukan di SD 2 Jambidan, Banguntapan, Bantul, Yogyakarta pada bulan Agustus 2019. Populasi penelitian adalah siswi kelas V dan VI di SD 2
Jambidan. Subjek dalam penelitian ini berjumlah 39 orang yang dipilih dengan tehnik pengambilan sampel purposive sampling.

Instrumen pengumpul data yang digunakan terdiri dari 2 kuesioner, yaitu kuesioner A dan kuesioner B. Kuesioner A berisi pertanyaan tentang karakteristik responden (inisial, usia, jenis kelamin, pengalaman responden mengikuti pendidikan kesehatan metode peer education serta pendidikan kesehatan menstruasi). Kuesioner B diadopsi dari Setiowati (2015) yang berisi 20 pertanyaan tentang kesiapan menghadapi menarche.

Uji normalitas data penelitian sudah dilakukan untuk melihat sebaran data dengan menggunakan Sphiro Wilk (sampel sedikit $\leq 50$ orang) dengan nilai selisih $\mathrm{p}=0,070$ $(p>0,05)$ dimana data memiliki distribusi normal sehingga Uji satistik yang digunakan Paired t test. Uji statistik Paired t test digunakan untuk melihat pengaruh pendidikan teman sebaya (peer education) kesehatan menstruasi terhadap kesiapan menghadapi menstruasi awal. Penelitian ini telah mendapatkan kelayakan etik dari Komisi Etik Penelitian dengan No 638/KEP-UNISA/V/2019.

\section{HASIL DAN PEMBAHASAN}

Karakteristik responden penelitian yaitu siswi kelas V dan VI di SD 2 Jambidan Banguntapan Bantul sebagaimana tercantum pada Tabel 1 . Pada tabel 1menunjukkan bahwa rata-rata siswi berusia 11 tahun sebanyak 22 siswi $(38,9 \%)$, sebagian siswi belum mengalami menstruasi sebanyak 34 siswi $(87,2 \%)$ dan terdapat siswi belum pernah mendapatkan informasi terkait menstruasi sebanyak 20 siswi $(51,3 \%)$. 


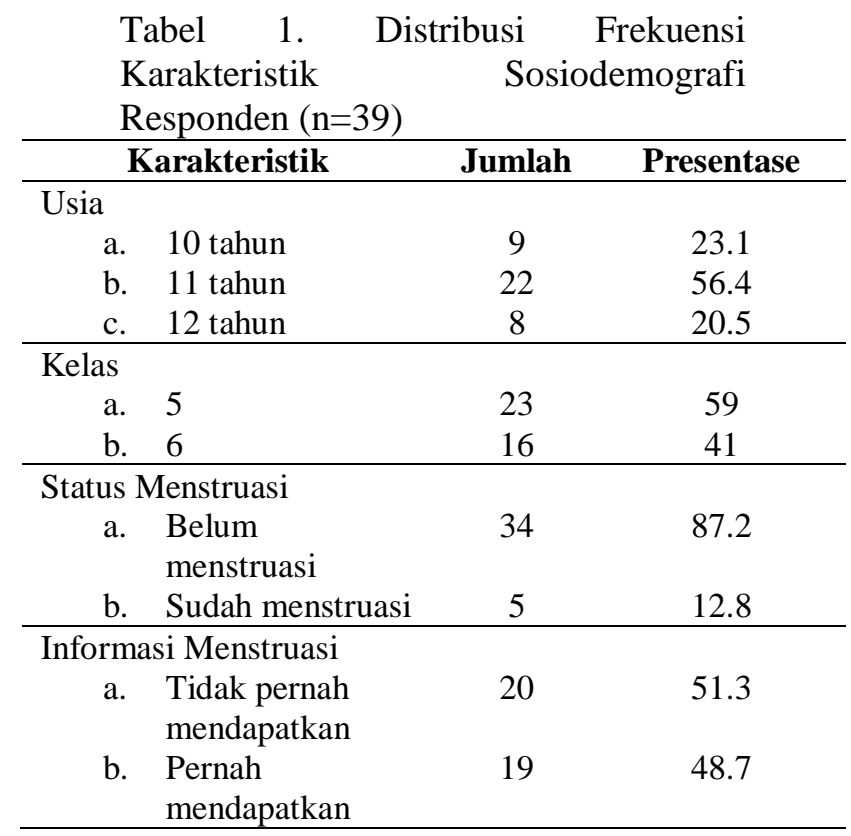

Tabel 3. Kesiapan Menghadapai Menstruasi Awal Siswi Sesudah Intervensi Peer Education Kesehatan Menstruasi $(\mathrm{n}=39)$

\begin{tabular}{cccc} 
No & Kesiapan & Jumlah & $\begin{array}{c}\text { Persentase } \\
(\mathbf{\%})\end{array}$ \\
\hline 1 & Kurang & 3 & 7,7 \\
2 & Cukup & 9 & 23,1 \\
3 & Baik & 27 & 69,2 \\
\hline & Jumlah & 39 & 100 \\
\hline
\end{tabular}

Tabel 3 menunjukkan bahwa kesiapan responden dalam menghadapi menstruasi awal sesudah intervensi peer education berada pada kategori baik sebanyak 27 $(69,2 \%)$ responden, sedangkan paling sedikit responden berada pada kategori kurang sebanyak $3(7,7 \%)$ responden.

Tabel 2. Kesiapan Menghadapi Menstruasi Awal Siswi Sebelum Intervensi Peer Education Kesehatan Menstruasi $(\mathrm{n}=39)$

\begin{tabular}{cccc}
\hline No & Kesiapan & Jumlah & $\begin{array}{c}\text { Persentase } \\
(\boldsymbol{\%})\end{array}$ \\
\hline 1 & Kurang & 7 & 17,9 \\
2 & Cukup & 16 & 41 \\
3 & Baik & 16 & 41 \\
\hline & Jumlah & 39 & 100 \\
\hline
\end{tabular}

Tabel 2 menunjukkan bahwa kesiapan responden dalam menghadapi menstruasi awal sebelum intervensi peer education berada pada kategori baik dan cukup sebanyak masing-masing 16 (41\%) responden, sedangkan paling sedikit responden berada pada kategori kurang sebanyak $7 \quad(17,9 \%)$ responden
Tabel 4. Distribusi Deskriptif Kesiapan Menghadapi Menstruasi Awal Siswi Sebelum dan Sesudah Intervensi Peer Education Kesehatan Menstruasi (n=39)

\begin{tabular}{lccccc}
\hline $\begin{array}{c}\text { Variabel } \\
\text { Kesiapan }\end{array}$ & $\begin{array}{c}\text { Mi } \\
\text { n }\end{array}$ & Max & $\begin{array}{c}\text { Mean } \\
\text { Medi }\end{array}$ & SD \\
Kesiapan & & & & & \\
$\begin{array}{l}\text { mengha- } \\
\text { dapi }\end{array}$ & 6.00 & 19.00 & 14.54 & 15.00 & 3.42 \\
$\begin{array}{l}\text { menarche } \\
\text { sebelum }\end{array}$ & & & & & \\
$\begin{array}{l}\text { peer } \\
\text { education }\end{array}$ & & & & & \\
\hline $\begin{array}{l}\text { Kesiapan } \\
\text { mengha- }\end{array}$ & 9.00 & 20.00 & 15.92 & 17.00 & 2.90 \\
dapi & & & & & \\
$\begin{array}{l}\text { menarche } \\
\text { sesudah } \\
\text { peer } \\
\text { education }\end{array}$ & & & & & \\
\hline
\end{tabular}

Hasil analisis tabel 4 didapat rata-rata nilai kesiapan responden menghadapi menstruasi awal sebelum intervensi peer education kesehatan menstruasi adalah 14.54 dan median 15.00 dengan standar deviasi 3.42. Nilai terendah adalah 6 dan tertinggi adalah 19. Sedangkan hasil analisis kesiapan responden menghadapi menstruasi awal sesudah intervensi peer education kesehatan menstruasi didapat 
rata-rata nilai kesiapan adalah 15.92 dengan median 17.00 dan standar deviasi 2.90. Nilai terendah adalah 9 dan tertinggi adalah 20. Nilai tertinggi yang telah dicapai oleh responden saat posttest sudah mencapai nilai maksimum yang dapat dicapai yaitu 20 .

Tabel 5. Distribusi Perbedaan Kesiapan Siswi Menghadapi Menstruasi Awal Siswi Sebelum dan Sesudah Intervensi Peer Education Kesehatan Menstruasi $(\mathrm{n}=39)$

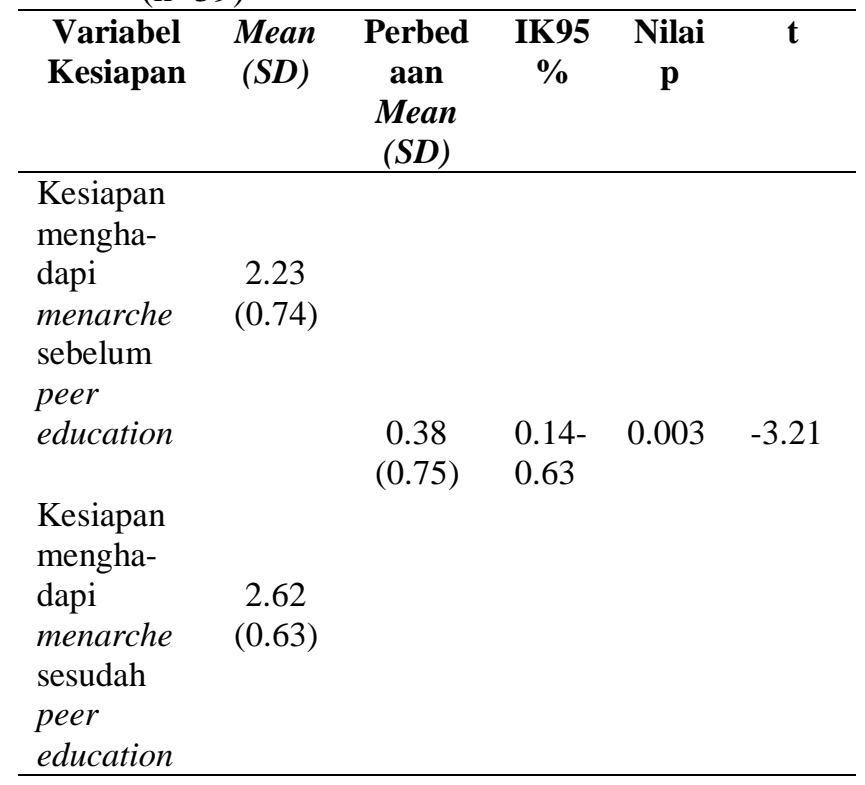

Tabel 5 menunjukkan bahwa terdapat perbedaan nilai rata-rata kesiapan antara pretest dan posttest sebesar 0.38 dengan standar deviasi 0.75 . Nilai $\mathrm{t}$ pada hasil penelitian menunjukkan kemaknaan atau seberapa besar pengaruh pemberian intervensi peer education kesehatan menstruasi terhadap kesiapan siswi menghadapi menstruasi awal, dimana nilai t yang didapatkan sebesar -3.21. nilai $t$ hitung ini lebih besar dari nilai $t$ tabel $(3.21>2.023)$. Hal ini menunjukkan bahwa terdapat perbedaan yang signifikan antara kesiapan sebelum dan sesudah intervensi peer education. Pada penelitian ini nilai t bernilai negatif, hal tersebut menunjukkan adanya peningkatan kesiapan siswi dimana pretest lebih kecil dari pada posttest. Dari hasil estimasi interval dapat diyakini sebesar 95\% selisih kesiapan sebelum intervensi peer education dengan kesiapan sesudah intervensi peer education adalah antara -0.14 sampai -0.63. Hasil uji $\mathrm{T}$ dependen didapatkan nilai signifikansi sebesar $0.003 \quad(\mathrm{p}<0.05)$ artinya terdapat perbedaan yang bermakna antara kesiapan siswi sebelum dan sesudah intervensi peer education kesehatan menstruasi. Tabel 5 juga menunjukkan bahwa ada pengaruh pendidikan kesehatan (peer education) kesehatan menstruasi terhadap kesiapan siswi menghadapi menarche di SD 2 Jambidan Banguntapan Bantul dibuktikan dengan $p$ value 0,003 signifikan.

Menstruasi pertama (menarche) merupakan salah satu kejadian terpenting pada masa pubertas remaja putri. Munculnya menstruasi awal merupakan tanda awal bahwa seorang anak perempuan mencapai kematangan fisik pada usia 10-16 tahun yang akan terjadi secara periodik (pada waktu tertentu) dan siklik (berulang-ulang). Anak perempuan yang akan menghadapi menstruasi awal membutuhkan kesiapan mental yang baik (Fajri \& Khairani, 2011).

Kesiapan menghadapi menstruasi awal merupakan keadaan yang menunjukkan seseorang siap untuk mencapai salah satu tanda kematangan fisik yaitu dialaminya menstruasi pertama (menarche) (Fajri \& Khairani, 2011). Terdapat tiga aspek mengenai kesiapan, yaitu adanya pemahaman, penghayatan, dan kesediaan. Pemahaman diartikan ketika seseorang mengerti dan mengetahui akan peristiwa yang sedang dialaminya sehingga membantu dirinya untuk merasa siap dalam menghadapi kejadian yang 
terjadi. Penghayatan merupakan kondisi dimana seseorang merasa siap dengan segala hal yang terjadi secara natural akan terjadi pada hampir setiap orang, merupkan sesuatu yang wajar, normal, juga tidak perlu dikhawatirkan. Penghayatan juga membuat seseorang merasakan keyakinan yang tinggi terkait pandangan agama. Sedangkan kesediaan adalah tindakan langsung terhadap kesempatan yang hadir, sehingga menjadi bagian pengalaman hidup (Yusuf et al., 2014).

Perbedaan kesiapan dapat terlihat pada anak yang siap dan tidak siap dalam menghadapi menstruasi awal. Hal ini dapat ditunjukkan dari sikapnya. Anak yang siap akan menunjukkan sikap positif, sedangkan anak yang tidak siap maka akan menunjukkan sikap yang negatif. Anak yang bersikap negatif (tidak siap) maka akan merasa kerepotan, kotor, tidak nyaman sehingga aktivitasnya akan terbatas dan emosinya akan cenderung naik turun. Beberapa alasan yang melatarbelakangi sikap negatif tersebut diantaranya adalah orang tua yang minim pendidikan seks pada anak. Pendidikan seks merupakan kewajiban setiap orangtua, terutama dijaman modern saat ini sehingga anak tidak merasa cemas dan lebih terbuka serta positif dalam menghadapi datangnya menstruasi awal yang berdampak langsung pada perubahan fisik serta psikologisnya. Hal ini sesuai dengan teori dari Suhaemi (2006) dalam Afiyah (2016) dimana setelah mengalami menstruasi pertama akan terjadi perubahan morfologis dan psikologis yang berpengaruh terhadap psikologis yang berupa cemas, takut, sakit, dan malu.

Beberapa faktor yang mempengaruhi kesiapan diantaranya adalah tingkat pengetahuan, usia, lingkungan, keadaan fisik, dukungan orangtua, dan sumber informasi. ${ }^{7}$ Hasil penelitian menunjukkan terdapat $20(51,3 \%)$ siswi yang tidak pernah mendapat informasi terkait menstruasi yang mempengaruhi kesiapan menghadapi menstruasi awal. Sejalan dengan penelitian Novitasari et al., yang menyimpulkan ada hubungan antara pengetahuan dengan kesiapan siswi menghadapi menstruasi awal dengan $p$ value 0,000 . Pada penelitian tersebut menyimpulkan terdapat 12 dari 35 responden yang mempunyai pengetahuan baik dan siap dalam menghadapi menarche (Novitasari et al, 2018).

Kesiapan menghadapi menstruasi awal pada dasarnya juga dapat dipersiapkan sejak dini oleh guru di sekolah. Anak yang sudah mendapatkan bekal pendidikan seks di rumah, kemudian didukung dengan pemberian dukungan informasi yang adekuat di sekolah tentunya akan memiliki kesiapan yang lebih baik. Salah satu media pendidikan kesehatan yang sesuai diterapkan pada anak sekolah adalah dengan peer education (pendidikan sebaya). Remaja pada usia 10-16 tahun sering membangun kerjasama antar teman dengan tujuan positif. Dengan interaksi antar teman sebaya, mereka bisa saling bertukar pengalaman atas apa yang sudah dihadapi misalnya pada remaja yang sedang menghadapi menstruasi pertama (Lutfiasari, 2015).

Pendidikan teman sebaya (peer education) yang diberikan pada penelitian ini adalah tentang kesehatan menstruasi. Topik yang didiskusikan adalah tentang kesehatan menstruasi meliputi pengertian menstruasi awal dan menstruasi, persiapan menghadapi menstruasi awal, kapan waktu 
datangnya menstruasi awal, perubahan yang dialami sebelum dan saat menstruasi terjadi, apa yang harus dilakukan saat menstruasi berlangsung, perineal hygiene saat menstruasi, serta manajemen nyeri saat menstruasi. Melalui proses diskusi anak belajar dan memperoleh pengalaman melalui teman sebayanya yang sudah mendapat menstruasi, sehingga terjadi proses transfer informasi.

Peer education merupakan kegiatan berbagi informasi and pengalaman diantara individu tentang sesuatu (Sandhu et al., 2013; Peel, 2009). Tujuannya untuk membantu anak dalam membangun pengetahuan, sikap, dan kemampuan yang sangat dibutuhkan untuk modifikasi perilaku yang positif dalam memunculkan pencegahan yang tidak mahal, dapat mudah diakses, dan sebagai dukungan psikososial. Program peer education fokus utamanya pada pemberian informasi penurunan bahaya, pencegahan, dan pemberian intervensi dini (Peel, 2009; Mason et al., 2011; Swartz et al., 2012).

Hasil penelitian menunjukkan adanya pengaruh pendidikan teman sebaya (peer education) terhadap kesiapan menghadapi menstruasi awal. Hal ini sejalan dengan penelitian Aswitami yang menyimpulkan bahwa terdapat pengaruh pendidikan kesehatan terhadap kesiapan psikologis menghadapi menstruasi awal dengan $p$ value 0,001 . Pada penelitian tersebut menyebutkan bahwa terdapat $74 \quad(93,7 \%)$ dari 75 responden yang siap menghadapi menstruasi awal (Aswitami, 2018).

Peer education sebagai salah satu intervensi utama terkait masalah kesehatan reproduksi remaja sudah pernah dilakukan dalam penelitian sebelumnya. Hasil review sistematis
Kim dan Free menyatakan walaupun masalah penurunan angka kehamilan pada remaja dan masalah perilaku lain terkait reproduksi remaja belum terbukti dengan peer education, namun peer education dapat meningkatkan kepatuhan responden perempuan untuk tidak melakukan hubungan seks sebelum menikah, serta peer education juga dapat meningkatkan pengetahuan, sikap, serta perhatian remaja terhadap kesehatan reproduksi (Qudsyi, 2015).

Pengetahuan dan persepsi remaja akan kesehatan reproduksi termasuk menstruasi dapat mempengaruhi dan dipengaruhi oleh teman sebayanya (peer). Jika teman sebayanya mempunyai pengetahuan yang mumpuni, maka remaja akan dapat menularkan pengetahuan yang dimilikinya kepada temannya. Sebaliknya, jika pengetahuan remaja rendah, maka yang akan tersebar di kalangan remaja adalah informasi yang tidak dapat dipertanggung jawabkan, termasuk keyakinankeyakihan atau paham atau mitos yang menyesatkan remaja. Menurut theory of reasoned action yang menyatakan bahwa persepsi seseorang tentang norma-norma sosial atau kepercayaan tentang apa yang orang, yang penting bagi individu, lakukan atau pikirkan tentang perilaku tertentu dapat mempengaruhi perubahan perilaku seseorang (Orr MG, Thrush R, Plaut DC, 2013). Dengan kata lain, sikap seseorang terhadap perubahan perilaku sangat dipengaruhi oleh pandangan mereka tentang konsekuensi positif atau negatifnya dan apa pendapat teman sebaya (peer) mereka tentang hal tersebut (Wye SQ et al., 2006 dalam Abdi dan Simbar, 2013). Pengetahuan yang benar yang didapat dari proses peer education ini akan 
mempengaruhi sikap dan kesiapan remaja menghadapi menstruasi awal.

Masalah budaya juga merupakan masalah klasik yang masih menjadi kendala dalam proses pendidikan kesehatan. Pada penelitian ini responden yang diteliti mayoritas berasal dari budaya jawa dimana orang jawa menganggap membicarakan tentang seksualitas termasuk menstruasi adalah hal yang tabu dan memalukan sehingga orang tua cenderung tidak membekali anaknya bagaimana mempersiapkan menstruasi awal dengan baik. Roqib mengatakan bahwa pembicaraan dan pengetahuan mengenai seks mengalir diantara teman akrab, kawan seprofesi, atau teman bermain, serta masalah seks juga tidak pernah dibicarakan secara terbuka dalam keluarga dan masyarakat jawa umumnya, walaupun dalam percakapan banyak lelucon mengenai seks. Teman akrab atau teman sebaya memiliki peran yang penting dalam menyebarkan informasi mengenai kesehatan reproduksi, sehingga jika orangtua kesulitan dalam memberikan pendidikan reproduksi dalam keluarga (dianggap tabu) maka pendidikan kesehatan tentang kesehatan reproduksi remaja dapat dilakukan melaui metode peer education (Roqib, 2007 dalam Qudsyi, 2015).

\section{KESIMPULAN}

Meningkatkan kesiapan remaja menghadapi menstruasi awal adalah penting adanya, salah satunya adalah dengan metode peer education. Berdasarkan uraian hasil penelitian menunjukan bahwa terdapat pengaruh pendidikan kesehatan (peer education) tentang kesehatan menstruasi terhadap kesiapan menghadapi menstruasi awal pada siswi SD 2 Jambidan Banguntapan Bantul Yogyakarta.

\section{SARAN}

Diharapkan metode peer education dapat diterapkan di sekolah sebagai metode pendidikan kesehatan pada siswa dalam upaya untuk meningkatkan kesiapan remaja putri dalam menghadapi menstruasi pertama/awal.

\section{UCAPAN TERIMA KASIH}

Terima kasih penulis ucapkan kepada pihak yang telah berkontribusi dalam penelitian:
a. Kemenristek DIKTI selaku pemberi hibah Penelitian Dosen Pemula Tahun 2019.
b. Rektor Universitas Aisyiyah Yogyakarta.
c. Ketua LPPM Universitas Aisyiyah Yogyakarta.
d. Guru dan Civitas Akademik SD 2 Jambidan Banguntapan Bantul yang telah membantu selama proses penelitian.

\section{REFERENSI}

Abdi, Fatemah., Simbar, Masoumeh. (2013). The Peer Education Approach in AdolescentsNarrative Review Article. Iranian J Publ Health, Vol. 42, No. 11, Nov 2013, pp.1200-1206.

Afiyah, R.Khairiyatul. (2016). Gambaran Respon Psikologis Saat Menarche pada Siswi Kelas 4-6 SD Khadijah, Surabaya. Jurnal Ilmiah Kesehatan, Vol. 9, No. 2, Agustus 2016, hal 209. 214

Aswitami. (2018). Pengaruh pendidikan kesehatan tentang menstruasi terhadap kesiapan psikologis menghadapi menarche pada remaja putri pra pubertas di SD Gugus V Mengwi. Skripsi. Stikes Bina Usada Bali

Fajri, A., \& Khairani, M. (2011). Hubungan antara komunikasi ibu-anak dengan kesiapan 
menghadapi menstruasi pertama (menarche) pada siswi Smp Muhammadiyah Banda Aceh. Jurnal Psikologi Undip, 10(2).

Gürkan, A. G. (2015). Üniversite Ögrencilerinin Premenstrual. Journal Süreyya Türk,1-14.

Hurlock. (2009). Psikologi Perkembangan Suatu Pendekatan Sepanjang Rentang Kehidupan. Gelora Aksara Pratama.

Janiwarty, B., \& Pieter,H.Z. (2013). Pendidikan Psikologi Untuk Bidan Suatu Teori Dan Terapannya. Yogyakarta: Rapha Publishing.

Jayanti, N. F., \& Purwanti, S. (2012). Deskripsi Faktor-Faktor yang Mempengaruhi Kesiapan Anak Dalam Menghadapi Menarche Di SDN 1 Kretek Kecamatan Paguyangan Kabupaten Brebes. Jurnal Bidan Prada, 1-14.

Kemenkes RI. (2014). Info Datin Pusat Data dan Informasi Kementrian Kesehatan Situasi Kesehatan Reproduksi Remaja dalam http://www.depkes.go.id. Diakses tanggal 14 Oktober 2017.

Lembaga Demografi FEB UI. (2017). Prioritaskan Kesehatan Reproduksi Remaja Untuk Menikmati Bonus Demografi. Diakses pada http://ldfebui.org/ wp- content/uploads/ 2017/08/ BN-06-2017.pdf tanggal 23 Agustus 2018.

Lutfiasari, Dessy. (2015). Pengaruh Pendidikan Kesehatan tentang menarche dan perubahan fisik sekunder melalui metode teman sebaya (peer group) terhadap persepsi remaja putri dalam menghadapi menarche di SDN Kampung Dalem 6 Kota Kediri.

Mason-Jones AJ, Flisher AJ, Mathews C. (2011). Who are the peer educators? HIV prevention in South African schools. Health Educ Res, 26(3):563-71.

Morta \& Farhat. (2010). Overview and sexually transmitted disease. The Journal of School nursing.

Novitasari,Silvia.,wardani, arwinanti. (2018). Hubungan pengetahuan tentang menstruasi terhadap kesiapan menghadapi menarche pada siswi SDN Asrikaton 1. Skripsi. Fakultas Ilmu Kesehatan Universitas Negeri Malang

Orr MG, Thrush R, Plaut DC. (2013). The Theory Of Reasoned Action As Parallel Constraint Satisfaction: Towards A Dynamic Computational Model Of Health Behavior. PLoS One, 8 (5): e62490.

Peel NM, Warburton J. (2009). Using senior volunteers as peer educators: What is the evidence of effectiveness in falls prevention? Australas J Ageing, 28(1):7-11.

Proverawati, A., \& Misaroh, S. (2009). Menarche Menstruasi Pertama Penuh Makna. Yogyakarta: Nuha Medika.

Puspita,I., Rosyidi,M., \& Wahyuni, S. (2015). Faktor-Faktor Yang Mempengaruhi Kesiapan Remaja Putri Menghadapi Menarche di SDNO2 Sukorejo Semarang. Skripsi tidak dipublikasikan. Semarang: Stikes Ngudi Waluyo.

Qudsyi, Hazhira. (2015). Program Peer Education Sebagai Media Alternatif Pendidikan Kesehatan Reproduksi Remaja di Indonesia. https://www.researchgate.net/pub lication/296831657

Sandhu S, Veinot P, Embuldeniya G, Brooks S, Sale J. (2013). Peer-topeer mentoring for individuals with early inflammatory arthritis: feasibility pilot. BMJ Open,3(3). pii: e002267. 
Setiowati, N. (2015). Hubungan Dukungan Ibu Dengan Kesiapan Menghadapi Menarche Pada Siswi Kelas $V$ dan VI MI Muhammadiyah Bonjor Tretep Temanggung. Skripsi tidak dipublikasikan. Yogyakarta: Program Studi Keperawatan Sekolah Tinggi Ilmu Kesehatan 'Aisyiyah.

Swartz S, Deutsch C, Makoae M, Michel B, Harding JH, Garzouzie G. (2012). Measuring change in vulnerable adolescents: findings from a peer education evaluation in South Africa. SAHARA J, 9(4):242-54.

Yusuf, Y., Rina K., \& Septi, R. (2014). Hubungan pengetahuan menarche dengan kesiapan remaja putrid menghadapi menarche di SMP Negeri 3 Tidore Kepulauan. Jurnal Keperawatan, 2(2). 